\title{
ANALISA PROKSEMIK PADA PERSEPSI PENGHALANG KANDANG DI KEBUN BINATANG
}

\author{
Mala Maulida, Deddy Wahjudi
}

Institut Teknologi Bandung . 087886030709

Email: Penulis1@gmail.com

\section{INFORMASI ARTIKEL}

Abstract: Besides functioning as a place for education and conservation, the zoo also functions as a place for recreation, all of these functions are interrelated with each other. Visitors play a major financial role for a zoo. This study investigates the perceived effect of enclosure barrier designs on visitor behavior in zoos. This is intended so that visitors can still have a pleasant experience but still respect animals by not engaging in negative behavior. So that the purpose of the zoo as a place of conservation, education and recreation can be enjoyed both from the side of animals and visitors. Visitors' perceptions and behavior were assessed using a questionnaire by presenting 6 design drawings of elephant enclosure barriers that are widely used in various parts of the world, such as dry ditches, wet ditches, iron rope barriers, glass barriers and two positions appear dominant and subordinate. 117 respondents responded to the proposed questionnaire whose results were analyzed using quantitative methods. The results of this study indicate that there is a significant effect on the perception of the cage barrier design on the behavior of respondents and the glass is the most preferred barrier because it allows visitors to observe elephants from a close distance, attracts visitors' interest and encourages them to watch the elephants longer and the addition of a dominant position design on animals has a positive effect because negative behavior tends to be small.

Keywords: Zoo, Proxemics, Elephant cage barrier, Visitor Visitors

\begin{abstract}
Abstrak: Selain berfungsi sebagai tempat pendidikan dan konservasi kebun binatang juga berfungsi sebagai tempat rekreasi, semua fungsi inipun saling terkait satu sama lain. Pengunjung memainkan peran finansial utama untuk sebuah kebun binatang. Penelitian ini menyelidiki efek persepsi desain penghalang kandang terhadap perilaku pengunjung di kebun binatang. Hal ini bertujuan agar pengunjung tetap mendapatkan pengalaman yang menyenangkan namun tetap memandang hormat satwa dengan tidak melakukan perilaku negatif. Sehingga tujuan kebun binatang sebagai tempat konservasi, pendidikan dan rekreasi dapat dinikmati dengan baik dari sisi satwa maupun pengunjungnya. Persepsi dan perilaku pengunjung dinilai menggunakan kuesioner dengan menyuguhkan 6 gambar desain penghalang kandang gajah yang banyak digunakan di berbagai belahan dunia, seperti parit kering, parit basah, penghalang tali besi, penghalang kaca dan dua posisi tampil dominan dan subordinal. 117 responden menanggapi kuisioner yang diajukan yang hasilnya dianalisis dengan menggunakan metode kuantitatif. Hasil penelitian ini menunjukan bahwa adanya pengaruh yang signifikan pada persepsi desain penghalang kandang terhadap perilaku responden dan kaca merupakan penghalang yang paling disukai karena memungkinkan pengunjung untuk mengamati gajah dari jarak dekat, menarik minat pengunjung dan mendorong mereka untuk menonton gajah lebih lama dan penambahan desain posisi dominan pada satwa memberikan efek positif karena perilaku negatif cendrung sedikit.
\end{abstract}

Kata Kunci: Kebun Binatang, Proksemika, Penghalang Kandang Gajah, Perilaku Pengunjung

Article history:

Received; 2020-11-25

Revised; 2021-04-10

Accepted; 2021-06-24 


\section{PENDAHULUAN}

Pada zaman modern ini kebun binatang bukan lagi hanya sebagai tempat untuk koservasi saja tetapi berdasarkan Peraturan Menteri Kehutanan Nomor P.53MENHUTII2006 tentang Lembaga Konservasi menjelaskan bahwa kebun binatang adalah suatu tempat yang mempunyai fungsi utama sebagai lembaga konservasi melalui kegiatan penyelamatan, rehabilitasi dan reinroduksi alam dan dimanfaatkan sebagi sarana pendidikan, penelitian, pengembangan ilmu pengetahuan dan teknologi, serta sarana rekreasi. Semua fungsi inipun saling terkait satu sama lain. Agar konservasi berlangsung efektif, dibutuhkan penelitian dan agar penelitian dapat dilakukan, diperlukan sumber daya. Pengunjung memainkan peran finansial utama untuk kebun binatang. Oleh sebab itu, kebun binatang perlu memastikan bahwa para pengunjung mendapatkan pengalaman yang menyenangkan dan menghibur (Hosey G, Melfi V , \& Pankhurst, 2013). Menurut Association of Zoos and Aquariums (AZA) Lebih dari 183 juta pengunjung pertahun di AS dan lebih dari 700 juta pengunjung di seluruh dunia yang datang ke kebun binatang, yang diantaranya 32\% orang dewasa dan 57\% anak-anak. Di Indonesia sendiri, di Ragunan data pengunjung pada tahun 2019 mencapai 5,4 juta pengunjung, sedangkan di Taman safari Indonesia mencapai 2 juta pengunjung setiap tahunnya. Dengan jumlah pengunjung sebanyak ini penting untuk memahami perilaku dan faktor yang mempengaruhi persepsi pengunjung terhadap kebun binatang, faktor-faktornya seperti desain kandang, waktu menonton dan ukuran, warna, aktivitas serta kelangkaan satwa (Whitworth, 2012; Mun et al., 2013 dalam (Chiew, Hemsworth, Sherwen, Melfi, \& Coleman, 2019). Beberapa penelitian terdahulu telah menemukan bahwa memodifikasi interaksi pengunjung dan satwa kebun binatang menggunakan cara intervensi atau manipulasi di area kandang seperti hambatan visual atau fisik, dapat mempengaruhi pengalaman pengunjung dan potensi perilaku pengunjung (Chiew, Hemsworth, Sherwen, Melfi, \& Coleman, 2019). Penghalang juga berfungsi sebagai pembatas untuk area satwa dan pengunjung. Batas tersebut dapat terlihat atau bahkan tidak disadari oleh pengunjung. Batas yang terlihat bisa berupa penghalang fisik seperti pagar beton, pagar besi, pagar kayu, dan kaca. Sedangkan untuk penghalang yang biasanya tidak disadari oleh pengunjung atau hambatan tersembunyi yaitu seperti parit kering, parit basah ataupun kenaikan level seperti trotoar. Selain penghalang fisik pengaturan posisi tampil juga menjadi isu menarik untuk desain kandang kebun binatang. Menurut (Coe,1985) posisi tampil yang menampilkan satwa pada posisi atas (mendominasi) lebih baik jika dibandingkan dengan pengunjung yang lebih mendominasi. Karena perilaku negatif yang dihasilkan oleh pengunjung cendrung lebih sedikit. Ide dominasi dan subordinasi antara manusia dan satwa menjadi isu yang dikembangkan untuk mengubah pola pikir pengunjung terhadap satwa, agar pengunjung tidak melihat keberadaan satwa sebagai objek, tetapi sebagai bagian dari ekosistem dan subjek yang dapat dipelajari (Roe, dkk, 2014 dalam (Slatch, 2015)).

Perilaku negatif pengunjung merupakan masalah juga yang harus dihadapi oleh beberapa kebun binatang di dunia termasuk di Indonesia. Biasanya ada beberapa masalah fisik dan psikologis yang berhubungan dengan desain penghalang (Gupta, 2008). Kasuskasus negatif yang sering terjadi, seperti melempar makanan, melempar benda, berusaha menyentuh satwa, dam memasuki kandang, hal ini akan berdampak pada kesejahteran satwa yang akhirnya menyebabkan para satwa menjadi stress dan sakit (Hemsworth \& Coleman, 2011).

Keberadaan gajah di kebun binatang penting karena status keberadaanya yang mulai terancam punah. Di Indonesia habitat asli gajah sudah mulai berkurang, sehingga gajah butuh perhatian lebih dalam perawatannya. Gajah merupakan satwa liar namun tidak termasuk kedalam kategori satwa buas, sehingga beberapa pengunjung lebih berani melakukan pemberian makan, memegang dan mencari perhatian di bandingkan dengan satwa lain seperti Singa. Padahal gajah juga bisa menjadi satwa yang berbahaya jika diganggu, penyerangan seperti menginjak dan menimpuk mungkin terjadi. 
Seringkali pengunjung tidak mengenali atau salah mengartikan interaksi yang dilakukan gajah terhadapnya, ia mengartikan beberapa gajah tertarik, malas atau galak, namun setiap interaksi yang dilakukan bisa jadi bagian dari pesan yang ingin disampaikan oleh gajah tentang ruang pribadinya. Menurut J.D Fisher ruang pribadi atau yang ia sebut ruang personal merupakan daerah atau lingkungan disekitar seseorang yang tidak terlihat dan menjadi wilayah pribadi yang tidak boleh dilalui oleh orang lain. Pada manusia, ruang personal di sebut dengan istilah proksemik Jika ruang tersebut dilanggar maka akan menyebabkan ketidak senangan dan seseorang akan menarik diri dari lingkungannya (Goffman dalam (Altman, 1975). Tujuan dari penelitian ini yaitu mengkaji pengaruh persepsi desain penghalang kandang terhadap perilaku pengunjung di kebun binatang. Hal ini bertujuan agar pengunjung tetap mendapatkan pengalaman yang menyenangkan namun tetap memandang hormat gajah dengan tidak melakukan perilaku negatif. Kajian mengenai pembatas dan hambatan kandang sudah pernah dilakukan oleh beberapa studi sebelumnya namun kajian tersebut masih belum membahas detail tentang tampilan desain penghalang seperti apa yang mampu mempengaruhi perilaku yang akan dilakukan pengunjung di kandang gajah.

\section{METODE PENELITIAN}

Dari tujuan penelitian yang telah dirumuskan bahwa peneliti ingin mencari pengaruh tampilan desain terhadap persepsi dan perilaku, maka penyelesaian masalah dalam penelitian ini yaitu :

1. Penelitian ini dilakukan pada enam desain penghalang gajah. Keenam desain terdiri dari dua posisi tampil dominan dan subordinal, penghalang kaca, parit kering, parit basah, dan penghalang tali besi.

2. Sebanyak 117 partisipan dalam penelitian ini yang usianya terdiri dari $11-35$ tahun keatas yang sebelumnya sudah pernah mengunjungi kebun binatang.

Penelitian ini mengacu kepada teori (Bitgood \& Patterson, 1987) dan beberapa teori lain, peneliti menyimpulkan bahwa desain dapat mempengaruhi persepsi dan perilaku seseorang. Sehingga beberapa variabel yang akan diuji pada penelitian ini yaitu variabel persepsi visual, variabel persepsi karakteristik hewan dan variabel persepsi perasaan. Kemudian mencari hubungan antara persepsi-persepsi tersebut terhadap perilaku pengunjung dengan cara menyebarkan kuisioner secara online. Pada kuisioner penghalang kandang di tampilkan dalam bentuk 3 gambar berdasarkan masing-masing desain penghalang. Selain mengacu kepada 3 teori (Bitgood \& Patterson, 1987) peneliti juga menambahkan variabel kesan yang sebutkan dalam penelitian D. L. Rhoads and r. J. Goldsworthy (2007).

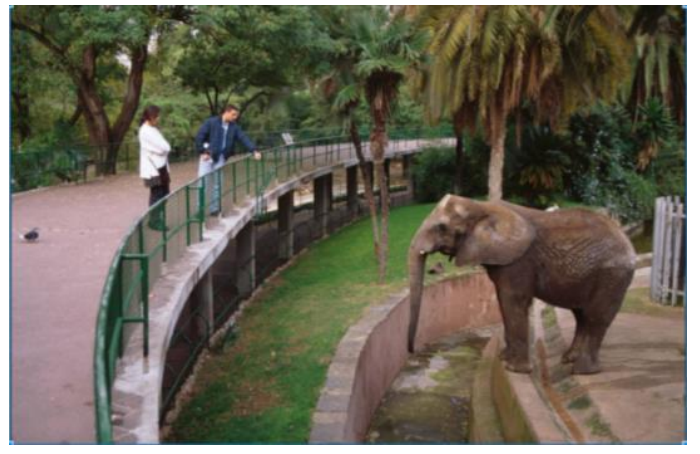

(1)

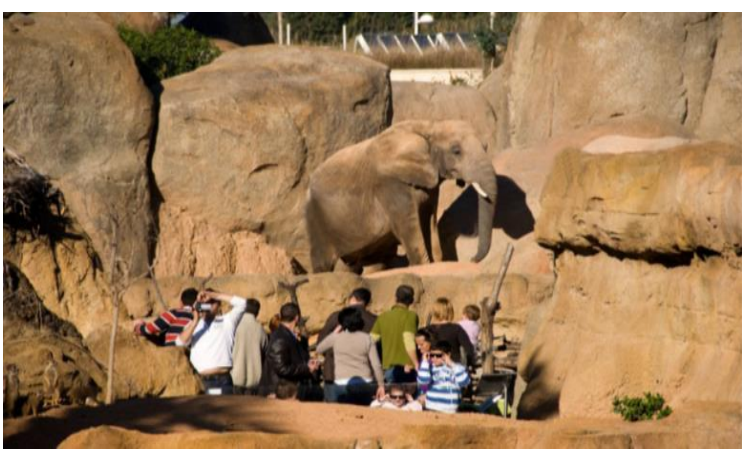

(2) 


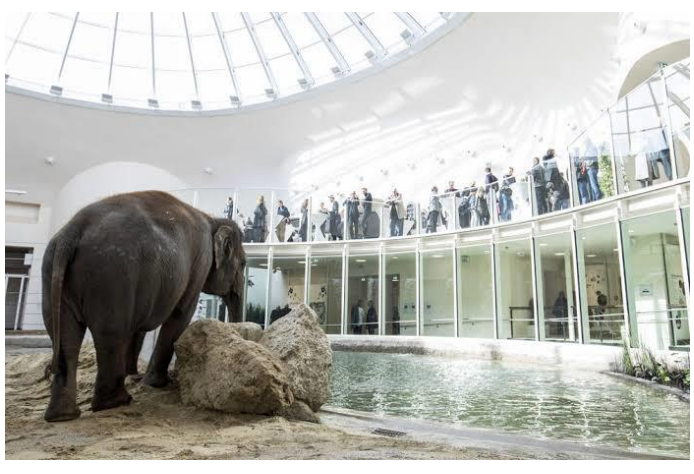

(3)

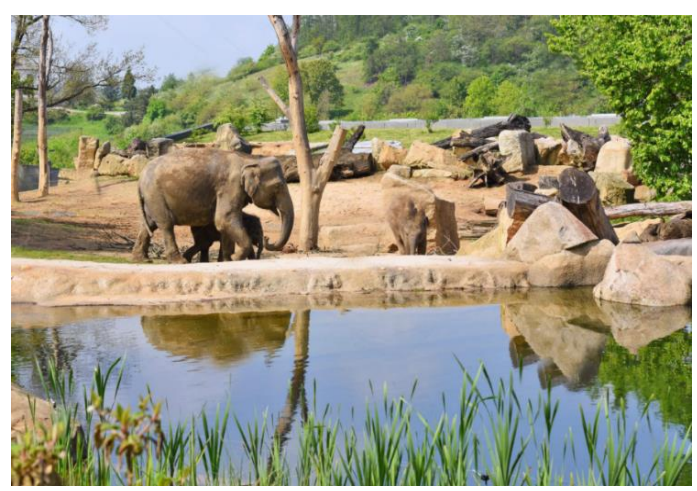

(5)

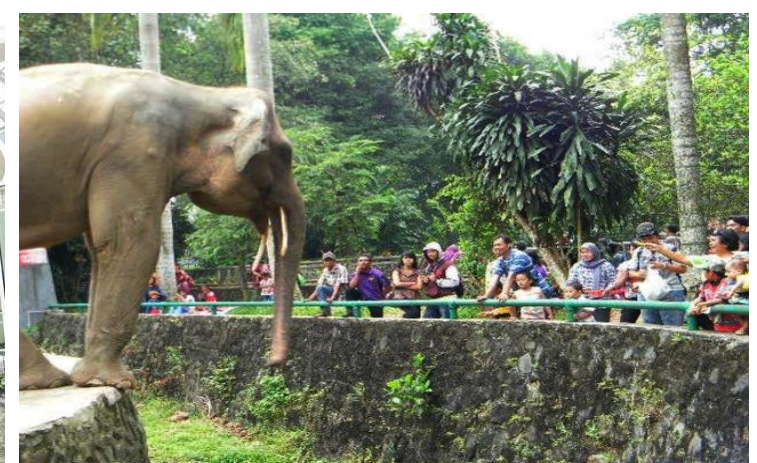

(4)

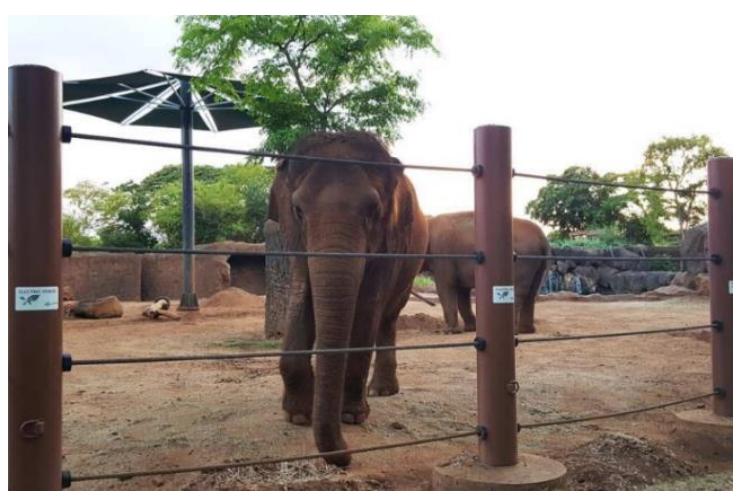

(6)

Gambar 1. (1) Posisi Dominan, (2) Posisi Subordinal, (3) Penghalang kaca, (4) Parit kering, (5) Parit Basah, (6) Penghalang tali besi

Untuk mencari tahu pengaruh dari setiap elemen variabel independent dan variabel dependen analisis data menggunakan uji korelasi linier berganda. Tujuannya agar variabel penelitian bisa menghasilkan data yang valid. Untuk itu perlunya melakukan uji validitas dan reliabilitas. Uji validitas dan reliabilitas ini hanya digunakan untuk mengukur pertanyaan topik penelitian. tahap pertama peneliti melakukan uji validitas dan reliabilitas, Tahap selanjutnya yaitu analisis komparatif k sampel, kemudian menganalisis faktor dengan teknik analisis Regresi linear berganda, dan terakhir melakukan perhitungan menggunakan software SPSS versi 25. Setelah perhitungan selesai, hasilnya dijabarkan secara deskriptif.

\section{Karakteristik pengunjung}

\section{HASIL DAN PEMBAHASAN}

Teknik sampling insidental digunakan untuk memilih responden pada penelitian ini, yaitu penentuan sampel berdasarkan kebetulan, atau dalam arti siapa saja dapat digunakan sebagai sampel. Karena total populasi pengunjung kebun binatang tidak terhingga. Sehingga perlu adanya pembatasan dalam penyebaran kuisioner dengan melibatkan 117 responden $(\mathrm{N}=117) .80$ orang responden berjenis kelamin perempuan dan terdapat 37 orang responden berjenis kelamin laki-laki. Kuisioner ini diisi oleh beberapa kategori usia diantaranya, 12 -17 tahun sebanyak 16 orang responden, 18 - 25 tahun sebanyak 97 orang responden, usia 26-35 tahun sebanyak 27 orang responden, dan usia 35 tahun keatas sebanyak 6 orang responden. Sehingga dapat disimpulkan bahwa kategori usia terbanyak berasal dari kalangan usia 18 25 tahun.

Usia responden didominasi oleh jenis kelamin perempuan pada kategori usia 18 - 25 tahun yang berjumlah 56 orang responden, sedangkan untuk yang berjenis kelamin laki-laki paling banyak juga pada kategori usia 18 - 25 tahun sebanyak 24 orang responden. Kemudian pada kategori usia 26 - 35 tahun menempati posisi kedua terbanyak dengan 
didominasi oleh perempuan sebanyak 13 orang responden, sedangkan untuk laki-laki sebanyak 10 responden. Dilanjutkan oleh kategori usia 12 -17 tahun dengan jumlah responden perempuan sebanyak 8 orang responden dan laki-laki 2 orang responden. Terakhir ada pada kategori usia $>35$ tahun keatas dengan jumlah responden sebanyak 4 orang yang terdiri dari 3 orang perempuan dan 1 laki-laki. Pada penelitian ini peneliti tidak melakukan pengujian pada kategori usia dikarenakan jumlah responden setiap kategori tidak signifikan. Berdasarkan hasil perhitungan alasan seseorang berkunjung ke kebun binatang adalah untuk keperluan rekreasi .Sebagian besar responden menjawab bahwa mereka berkunjung ke kebun binatang biasanya bersama keluarga teman yang jumlahnya $>3$ orang.

Penggunaan uji analisis regresi linear dilakukan untuk mengetahui apakah model regresi baik (linear) atau tidak secara signifikan (Ghozali, 2011). Uji normalitas data pada tahap ini mengunakan uji P-P plot atau yang sering disebut uji normal probability plot yang dapat dilihat pada grafik histogram. Setelah membahas hasil uji analisis normalitas data pada setiap desain 1 sampai 6 maupun desain keseluruhan, maka peneliti menyimpulkan bahwa keseluruhan data dinyatakan normal (positif) karena seluruh titik (data) menyebar dan mengikuti arah diagonal. Selanjutnya tahap uji peneliti melakukan analisis antar variabel dengan menggunakan metode Regresi Linier, dimana metode ini digunakan untuk mencari pengaruh hubungan antara 1 variabel dengan 1 variabel atau lebih lain yang dilihat dari nilai positif dan negatifnya. Tahap ini menganalisa pengaruh elemen Desain penghalang kandang terhadap kesan dan perilaku pengunjung di kebun binatang. Setelah dilakukan uji analisis korelasi berganda pada hubungan antara desain penghalang kandang dengan variabel persepsi visual, karakteristik hewan yang dipamerkan dan variabel kesan, peneliti kemudian menganalisis keseluruhan variabel persepsi terhadap variabel perilaku.

\section{Hasil Uji Signifikansi Variabel Persepsi}

Berikut merupakan hasil dari hasil uji signifikansi variabel persepsi, yaitu:

Tabel 1. Hasil Uji Signifikansi Variabel Persepsi

\begin{tabular}{|c|c|c|c|c|c|c|c|}
\hline KENYAMANAN & Desain 1 & Desain 2 & & Desain 3 & Desain 4 & Desain 5 & Desain 6 \\
\hline Desain 1 & & & $-2.000^{*}$ & .350 & -.316 & -.154 & $-.880^{*}$ \\
\hline Desain 2 & $2.000^{*}$ & & & $2.350^{*}$ & $1.684^{*}$ & $1.846^{*}$ & $1.120^{*}$ \\
\hline Desain 3 & -.350 & & $-2.350^{*}$ & & $-.667^{*}$ & $-.504^{*}$ & $-1.231^{*}$ \\
\hline Desain 4 & .316 & & $-1.684^{*}$ & $.667^{*}$ & & .162 & $-.564^{*}$ \\
\hline Desain 5 & .154 & & $-1.846^{*}$ & $.504^{*}$ & -.162 & & $-.726^{*}$ \\
\hline Desain 6 & $.880^{*}$ & & $-1.120^{*}$ & $1.231^{*}$ & $.564^{*}$ & $.726^{*}$ & \\
\hline $\begin{array}{l}\text { KONSEP } \\
\text { DESAIN }\end{array}$ & Desain 1 & Desain 2 & & Desain 3 & Desain 4 & Desain 5 & Desain 6 \\
\hline Desain 1 & & & .103 & $.906^{*}$ & -.385 & $.692^{*}$ & $-.521^{*}$ \\
\hline Desain 2 & -.103 & & & $.803^{*}$ & $-.487^{*}$ & $.590^{*}$ & $-.624^{*}$ \\
\hline Desain 3 & $-.906^{*}$ & & $-.803^{*}$ & & $-1.291^{*}$ & -.214 & $-1.427^{*}$ \\
\hline Desain 4 & .385 & & $.487^{*}$ & $1.291^{*}$ & & $1.077^{*}$ & -.137 \\
\hline Desain 5 & $-.692^{*}$ & & $-.590^{*}$ & .214 & $-1.077^{*}$ & & $-1.214^{*}$ \\
\hline Desain 6 & $.521^{*}$ & & $.624^{*}$ & $1.427^{*}$ & .137 & $1.214^{*}$ & \\
\hline LUAS & Desain 1 & Desain 2 & & Desain 3 & Desain 4 & Desain 5 & Desain 6 \\
\hline
\end{tabular}

\begin{tabular}{|c|c|c|c|c|c|c|c|}
\hline Desain 1 & & & $-1.000^{*}$ & -.137 & -.231 & .385 & $-1.154^{*}$ \\
\hline Desain 2 & $1.000^{*}$ & & & $.863^{*}$ & $.769^{*}$ & $1.385^{*}$ & -.154 \\
\hline Desain 3 & .137 & & $-.863^{*}$ & & -.094 & $.521^{*}$ & $-1.017^{*}$ \\
\hline Desain 4 & .231 & & $-.769^{*}$ & .094 & & $.615^{*}$ & $-.923^{*}$ \\
\hline Desain 5 & -.385 & & $-1.385^{*}$ & $-.521^{*}$ & $-.615^{*}$ & & $-1.538^{*}$ \\
\hline Desain 6 & $1.154^{*}$ & & .154 & $1.017^{*}$ & $.923^{*}$ & $1.538^{*}$ & \\
\hline $\begin{array}{l}\text { TERLIHAT } \\
\text { ALAMI }\end{array}$ & Desain 1 & Desain 2 & & Desain 3 & Desain 4 & Desain 5 & Desain 6 \\
\hline Desain 1 & & & -.393 & -.214 & .239 & $.880^{*}$ & $-.838^{*}$ \\
\hline Desain 2 & .393 & & & .179 & $.632^{*}$ & $1.274^{*}$ & $-.444^{*}$ \\
\hline
\end{tabular}




\begin{tabular}{|c|c|c|c|c|c|c|c|}
\hline Desain 3 & .214 & & -.179 & & $.453^{*}$ & $1.094^{*}$ & $-.624^{*}$ \\
\hline Desain 4 & -.239 & & $-.632^{*}$ & $-.453^{*}$ & & $.641^{*}$ & $-1.077^{*}$ \\
\hline Desain 5 & $-.880^{*}$ & & $-1.274^{*}$ & $-1.094^{*}$ & $-.641^{*}$ & & $-1.718^{*}$ \\
\hline Desain 6 & $.838^{*}$ & & $.444^{*}$ & $.624^{*}$ & $1.077^{*}$ & $1.718^{*}$ & \\
\hline $\begin{array}{l}\text { KEDEKATAN } \\
\text { SATWA }\end{array}$ & Desain 1 & Desain 2 & & Desain 3 & Desain 4 & Desain 5 & Desain 6 \\
\hline Desain 1 & & & .368 & $.744^{*}$ & -.103 & -.359 & $.838^{*}$ \\
\hline Desain 2 & -.368 & & & .376 & -.470 & $-.726^{*}$ & .470 \\
\hline Desain 3 & $-.744^{*}$ & & -.376 & & $-.846^{*}$ & $-1.103^{*}$ & .094 \\
\hline Desain 4 & .103 & & .470 & $.846^{*}$ & & -.256 & $.940^{*}$ \\
\hline Desain 5 & .359 & & $.726^{*}$ & $1.103^{*}$ & .256 & & $1.197^{*}$ \\
\hline Desain 6 & $-.838^{*}$ & & -.470 & -.094 & $-.940^{*}$ & $-1.197^{*}$ & \\
\hline $\begin{array}{l}\text { GERAKAN } \\
\text { SATWA }\end{array}$ & Desain 1 & Desain 2 & & Desain 3 & Desain 4 & Desain 5 & Desain 6 \\
\hline Desain 1 & & -.282 & & -.103 & -.085 & .427 & $-.590^{*}$ \\
\hline Desain 2 & .282 & & & .179 & .197 & $.709^{*}$ & -.308 \\
\hline Desain 3 & .103 & & -.179 & & .017 & $.530^{*}$ & $-.487^{*}$ \\
\hline Desain 4 & .085 & & -.197 & -.017 & & $.513^{*}$ & $-.504^{*}$ \\
\hline Desain 5 & -.427 & & $-.709^{*}$ & $-.530^{*}$ & $-.513^{*}$ & & $-1.017^{*}$ \\
\hline Desain 6 & $.590^{*}$ & & .308 & $.487^{*}$ & $.504^{*}$ & $1.017^{*}$ & \\
\hline $\begin{array}{l}\text { KEJELASAN } \\
\text { SATWA }\end{array}$ & Desain 1 & Desain 2 & & Desain 3 & Desain 4 & Desain 5 & Desain 6 \\
\hline Desain 1 & & & $-.718^{*}$ & .299 & -.094 & $-.581^{*}$ & -.077 \\
\hline Desain 2 & $.718^{*}$ & & & $1.017^{*}$ & $.624^{*}$ & .137 & $.641^{*}$ \\
\hline Desain 3 & -.299 & & $-1.017^{*}$ & & -.393 & $-.880^{*}$ & -.376 \\
\hline Desain 4 & .094 & & $-.624^{*}$ & .393 & & $-.487^{*}$ & .017 \\
\hline Desain 5 & $.581^{*}$ & & -.137 & $.880^{*}$ & $.487^{*}$ & & $.504^{*}$ \\
\hline Desain 6 & .077 & & $-.641^{*}$ & .376 & -.017 & $-.504^{*}$ & \\
\hline $\begin{array}{l}\text { KEBUASAN } \\
\text { SATWA }\end{array}$ & Desain 1 & Desain 2 & & Desain 3 & Desain 4 & Desain 5 & Desain 6 \\
\hline Desain 1 & & & $.675^{*}$ & -.009 & .359 & $.556^{*}$ & .291 \\
\hline Desain 2 & $-.675^{*}$ & & & $-.684^{*}$ & -.316 & -.120 & -.385 \\
\hline Desain 3 & .009 & & $.684^{*}$ & & .368 & $.564^{*}$ & .299 \\
\hline Desain 4 & -.359 & & .316 & -.368 & & .197 & -.068 \\
\hline Desain 5 & $-.556^{*}$ & & .120 & $-.564^{*}$ & -.197 & & -.265 \\
\hline Desain 6 & -.291 & & .385 & -.299 & .068 & .265 & \\
\hline SUKA & Desain 1 & Desain 2 & & Desain 3 & Desain 4 & Desain 5 & Desain 6 \\
\hline Desain 1 & & & $-1.573^{*}$ & .248 & -.427 & -.051 & $-.812^{*}$ \\
\hline Desain 2 & $1.573^{*}$ & & & $1.821^{*}$ & $1.145^{*}$ & $1.521^{*}$ & $.761^{*}$ \\
\hline Desain 3 & -.248 & & $-1.821^{*}$ & & $-.675^{*}$ & -.299 & $-1.060^{*}$ \\
\hline Desain 4 & .427 & & $-1.145^{*}$ & $.675^{*}$ & & .376 & -.385 \\
\hline Desain 5 & .051 & & $-1.521^{*}$ & .299 & -.376 & & $-.761^{*}$ \\
\hline Desain 6 & $.812^{*}$ & & $-.761^{*}$ & $1.060^{*}$ & .385 & $.761^{*}$ & \\
\hline MENARIK & Desain 1 & Desain 2 & & Desain 3 & Desain 4 & Desain 5 & Desain 6 \\
\hline Desain 1 & & & $-.863^{*}$ & $.496^{*}$ & -.393 & .137 & $-.761^{*}$ \\
\hline Desain 2 & $.863^{*}$ & & & $1.359^{*}$ & $.470^{*}$ & $1.000^{*}$ & .103 \\
\hline Desain 3 & $-.496^{*}$ & & $-1.359^{*}$ & & $-.889^{*}$ & -.359 & $-1.256^{*}$ \\
\hline Desain 4 & .393 & & $-.470^{*}$ & $.889^{*}$ & & $.530^{*}$ & -.368 \\
\hline Desain 5 & -.137 & & $-1.000^{*}$ & .359 & $-.530^{*}$ & & $-.897^{*}$ \\
\hline Desain 6 & $.761^{*}$ & & -.103 & $1.256^{*}$ & .368 & $.897^{*}$ & \\
\hline BOSAN & Desain 1 & Desain 2 & & Desain 3 & Desain 4 & Desain 5 & Desain 6 \\
\hline Desain 1 & & $-.470^{*}$ & & .350 & -.026 & .137 & $-.692^{*}$ \\
\hline Desain 2 & $.470^{*}$ & & & $.821^{*}$ & $.444^{*}$ & $.607^{*}$ & -.222 \\
\hline Desain 3 & -.350 & & $-.821^{*}$ & & -.376 & -.214 & $-1.043^{*}$ \\
\hline Desain 4 & .026 & & $-.444^{*}$ & .376 & & .162 & $-.667^{*}$ \\
\hline Desain 5 & -.137 & & $-.607^{*}$ & .214 & -.162 & & $-.829^{*}$ \\
\hline Desain 6 & $.692^{*}$ & & .222 & $1.043^{*}$ & $.667^{*}$ & $.829^{*}$ & \\
\hline BАНAYA & Desain 1 & Desain 2 & & Desain 3 & Desain 4 & Desain 5 & Desain 6 \\
\hline Desain 1 & & & $-2.137^{*}$ & .402 & $-.513^{*}$ & -.393 & $-.983^{*}$ \\
\hline
\end{tabular}




\begin{tabular}{|c|c|c|c|c|c|c|c|}
\hline Desain 2 & $2.137^{*}$ & & & $2.538^{*}$ & $1.624^{*}$ & $1.744^{*}$ & $1.154^{*}$ \\
\hline Desain 3 & -.402 & & $-2.538^{*}$ & & $-.915^{*}$ & $-.795^{*}$ & $-1.385^{*}$ \\
\hline Desain 4 & $.513^{*}$ & & $-1.624^{*}$ & $.915^{*}$ & & .120 & $-.470^{*}$ \\
\hline Desain 5 & .393 & & $-1.744^{*}$ & $.795^{*}$ & -.120 & & $-.590^{*}$ \\
\hline Desain 6 & $.983^{*}$ & & $-1.154^{*}$ & $1.385^{*}$ & $.470^{*}$ & $.590^{*}$ & \\
\hline $\begin{array}{l}\text { MELIHAT } \\
\text { KEJELASAN } \\
\text { SATWA } \\
\end{array}$ & Desain 1 & Desain 2 & & Desain 3 & Desain 4 & Desain 5 & Desain 6 \\
\hline Desain 1 & & & $-.692^{*}$ & .299 & -.077 & -.376 & -.171 \\
\hline Desain 2 & $.692^{*}$ & & & $.991^{*}$ & $.615^{*}$ & .316 & $.521^{*}$ \\
\hline Desain 3 & -.299 & & $-.991^{*}$ & & -.376 & $-.675^{*}$ & $-.470^{*}$ \\
\hline Desain 4 & .077 & & $-.615^{*}$ & .376 & & -.299 & -.094 \\
\hline Desain 5 & .376 & & -.316 & $.675^{*}$ & .299 & & .205 \\
\hline Desain 6 & .171 & & $-.521^{*}$ & $.470^{*}$ & .094 & -.205 & \\
\hline $\begin{array}{l}\text { DEKAT } \\
\text { PENGHALANG }\end{array}$ & Desain 1 & Desain 2 & & Desain 3 & Desain 4 & Desain 5 & Desain 6 \\
\hline Desain 1 & & & $-1.376^{*}$ & .214 & -.188 & -.350 & $-.735^{*}$ \\
\hline Desain 2 & $1.376^{*}$ & & & $1.590^{*}$ & $1.188^{*}$ & $1.026^{*}$ & $.641^{*}$ \\
\hline Desain 3 & -.214 & & $-1.590^{*}$ & & $-.402^{*}$ & $-.564^{*}$ & $-.949^{*}$ \\
\hline Desain 4 & .188 & & $-1.188^{*}$ & $.402^{*}$ & & -.162 & $-.547^{*}$ \\
\hline Desain 5 & .350 & & $-1.026^{*}$ & $.564^{*}$ & .162 & & -.385 \\
\hline Desain 6 & $.735^{*}$ & & $-.641^{*}$ & $.949^{*}$ & $.547^{*}$ & .385 & \\
\hline $\begin{array}{l}\text { INGIN LEBIH } \\
\text { TAHU }\end{array}$ & Desain 1 & Desain 2 & & Desain 3 & Desain 4 & Desain 5 & Desain 6 \\
\hline Desain 1 & & & $-.709^{*}$ & $.410^{*}$ & -.103 & .017 & $-.427^{*}$ \\
\hline Desain 2 & $.709^{*}$ & & & $1.120^{*}$ & $.607^{*}$ & $.726^{*}$ & .282 \\
\hline Desain 3 & $-.410^{*}$ & & $-1.120^{*}$ & & $-.513^{*}$ & $-.393^{*}$ & $-.838^{*}$ \\
\hline Desain 4 & .103 & & $-.607^{*}$ & $.513^{*}$ & & .120 & -.325 \\
\hline Desain 5 & -.017 & & $-.726^{*}$ & $.393^{*}$ & -.120 & & $-.444^{*}$ \\
\hline Desain 6 & $.427^{*}$ & & -.282 & $.838^{*}$ & .325 & $.444^{*}$ & \\
\hline $\begin{array}{l}\text { MEMANGGIL } \\
\text { SATWA }\end{array}$ & Desain 1 & Desain 2 & & Desain 3 & Desain 4 & Desain 5 & Desain 6 \\
\hline Desain 1 & & & $-.821^{*}$ & -.197 & -.214 & -.333 & $-.547^{*}$ \\
\hline Desain 2 & $.821^{*}$ & & & $.624^{*}$ & $.607^{*}$ & $.487^{*}$ & .274 \\
\hline Desain 3 & .197 & & $-.624^{*}$ & & -.017 & -.137 & -.350 \\
\hline Desain 4 & .214 & & $-.607^{*}$ & .017 & & -.120 & -.333 \\
\hline Desain 5 & .333 & & $-.487^{*}$ & .137 & .120 & & -.214 \\
\hline Desain 6 & $.547^{*}$ & & -.274 & .350 & .333 & .214 & \\
\hline $\begin{array}{l}\text { MELEMPAR } \\
\text { SESUATU KE } \\
\text { KANDANG }\end{array}$ & Desain 1 & Desain 2 & & Desain 3 & Desain 4 & Desain 5 & Desain 6 \\
\hline Desain 1 & & & -.350 & $.752^{*}$ & .128 & .043 & .077 \\
\hline Desain 2 & .350 & & & $1.103^{*}$ & $.479^{*}$ & .393 & .427 \\
\hline Desain 3 & $-.752^{*}$ & & $-1.103^{*}$ & & $-.624^{*}$ & $-.709^{*}$ & $-.675^{*}$ \\
\hline Desain 4 & -.128 & & $-.479^{*}$ & $.624^{*}$ & & -.085 & -.051 \\
\hline Desain 5 & -.043 & & -.393 & $.709^{*}$ & .085 & & .034 \\
\hline Desain 6 & -.077 & & -.427 & $.675^{*}$ & .051 & -.034 & \\
\hline WASPADA & Desain 1 & Desain 2 & & Desain 3 & Desain 4 & Desain 5 & Desain 6 \\
\hline Desain 1 & & & .385 & $-.624^{*}$ & -.051 & -.197 & .128 \\
\hline Desain 2 & -.385 & & & $-1.009^{*}$ & $-.436^{*}$ & $-.581^{*}$ & -.256 \\
\hline Desain 3 & $.624^{*}$ & & $1.009^{*}$ & & $.573^{*}$ & $.427^{*}$ & $.752^{*}$ \\
\hline Desain 4 & .051 & & $.436^{*}$ & $-.573^{*}$ & & -.145 & .179 \\
\hline Desain 5 & .197 & & $.581^{*}$ & $-.427^{*}$ & .145 & & .325 \\
\hline Desain 6 & -.128 & & .256 & $-.752^{*}$ & -.179 & -.325 & \\
\hline $\begin{array}{l}\text { MEMEGANG } \\
\text { SATWA } \\
\end{array}$ & Desain 1 & Desain 2 & & Desain 3 & Desain 4 & Desain 5 & Desain 6 \\
\hline Desain 1 & & -.419 & & -.205 & -.154 & -.282 & -.043 \\
\hline Desain 2 & .419 & & & .214 & .265 & .137 & .376 \\
\hline Desain 3 & .205 & & -.214 & & .051 & -.077 & .162 \\
\hline
\end{tabular}




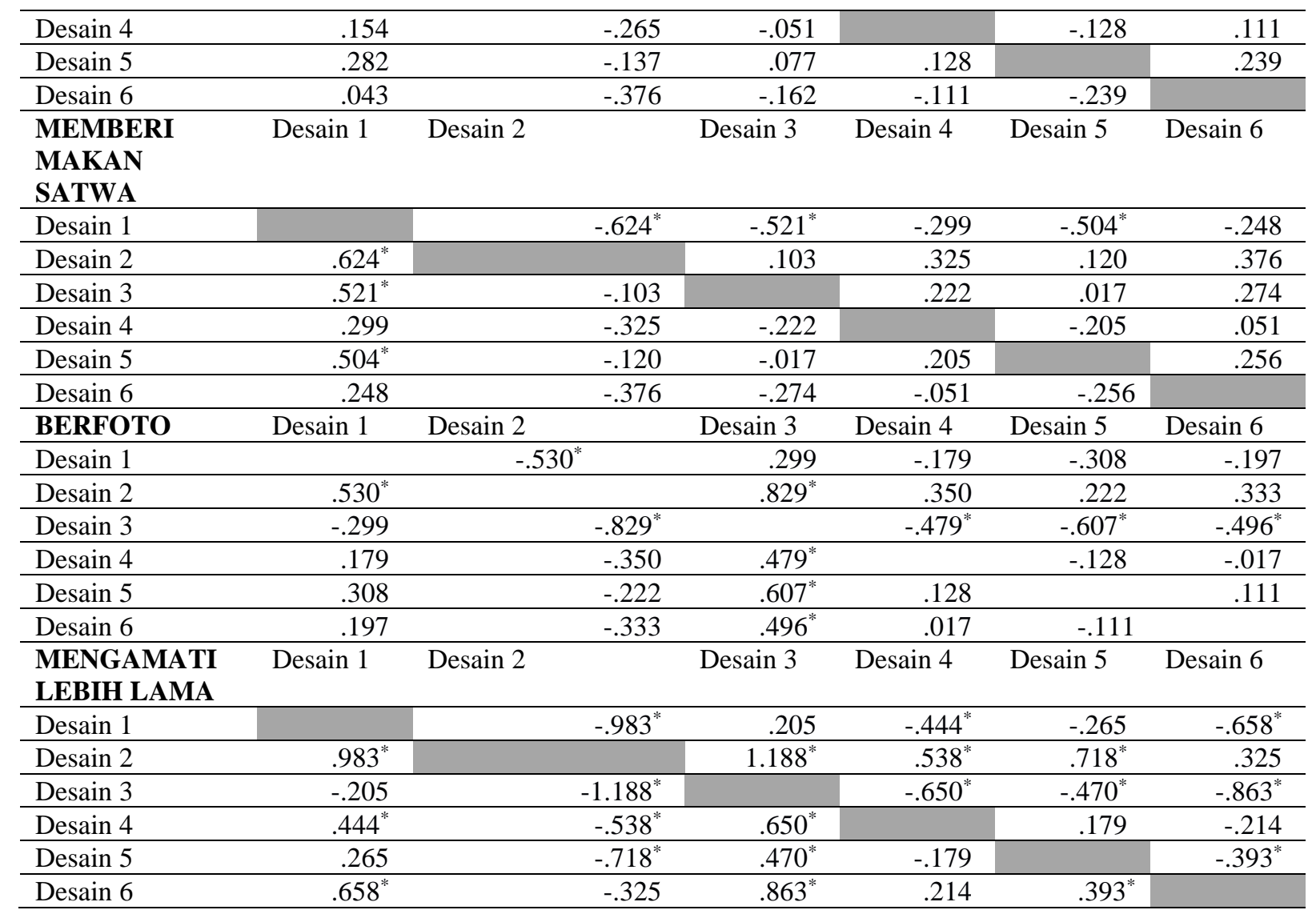

Pada tabel 1 di atas baris dan kolom pertama terdapat variabel (cetak tebal) semantic differential. Enam baris ke kanan dan enam ke bawah merupakan desain penghalang kandang yang dibandingkan. Nilai yang berisi tanda bintang $(*)$ berarti terdapat perbedaan yang signifikan pada rata-rata $(M D=$ Mean Difference $)$ desain desain penghalang tersebut. Nilai minus (-) berarti $M D$ desain tersebut lebih rendah sebaliknya jika tidak terdapat minus berarti $M D$ desain produk lebih besar dibandingkan produk yang dibandingkan.

Misalnya, pada variabel ramah lingkungan; Reflection (baris pertama kolom kedua) dibandingkan dengan posisi subordinal (desain 2); $M D$-nya $0.983 *$ berarti posisi dominan (desain 1) secara signifikan dipersepsikan pengunjung lebih ingin mengamati lebih lama dibandingkan posisi subordinal (desain 2). Atau lebih mudahnya untuk mengetahui desain mana yang paling unggul lihat dari desain mana yang memiliki keseluruhan nilai plus. Sedangkan untuk mengetahui desain mana yang paling lemah dapat dilihat dari desain mana yang memiliki keseluruhan nilai minus. Hasil dari perhitungan diatas disimpulkan sebagai berikut:

Tabel 2. Kesimpulan hasil Uji Signifikansi Variabel Persepsi

\begin{tabular}{|c|c|c|c|c|c|c|}
\hline PERSEPSI & $\begin{array}{c}\text { Posisi } \\
\text { Dominan } \\
\text { (Desain 1) }\end{array}$ & $\begin{array}{c}\text { Posisi } \\
\text { subordinal } \\
\text { (Desain 2) }\end{array}$ & $\begin{array}{l}\text { Penghalang } \\
\text { kaca } \\
\text { (Desain 3) }\end{array}$ & $\begin{array}{c}\text { Parit } \\
\text { kering } \\
\text { (Desain } \\
4)\end{array}$ & $\begin{array}{c}\text { Parit } \\
\text { basah } \\
\text { (Desain } \\
\text { 5) }\end{array}$ & $\begin{array}{c}\text { Penghalang tali } \\
\text { besi } \\
\text { (Desain 6) }\end{array}$ \\
\hline Kenyamanan & & & $\checkmark$ & & & \\
\hline keunikan & & & $\checkmark$ & & & \\
\hline Luas kandang & & & & & $\checkmark$ & \\
\hline kealamian & & & & & $\checkmark$ & \\
\hline Kedekatan & & & & & & $\checkmark$ \\
\hline Gerak bebas & & & & & $\checkmark$ & \\
\hline Kejelasan satwa & & & $\checkmark$ & & & \\
\hline Kebuasan & & $\checkmark$ & & & & \\
\hline
\end{tabular}




\begin{tabular}{|c|c|c|c|c|c|c|}
\hline PERSEPSI & $\begin{array}{c}\text { Posisi } \\
\text { Dominan } \\
\text { (Desain 1) }\end{array}$ & $\begin{array}{c}\text { Posisi } \\
\text { subordinal } \\
\text { (Desain 2) }\end{array}$ & 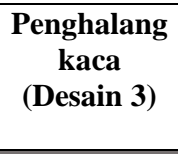 & $\begin{array}{c}\text { Parit } \\
\text { kering } \\
\text { (Desain } \\
4)\end{array}$ & $\begin{array}{c}\text { Parit } \\
\text { basah } \\
\text { (Desain } \\
5 \text { ) }\end{array}$ & $\begin{array}{c}\text { Penghalang tali } \\
\text { besi } \\
\text { (Desain 6) }\end{array}$ \\
\hline Kesukaan & & & $\checkmark$ & & & \\
\hline Ketertarikan & & & $\checkmark$ & & & \\
\hline Kebosanan & & & & & & $\checkmark$ \\
\hline Bahaya & & $\checkmark$ & & & & \\
\hline Kejelasan satwa & & tidak & ya & & & \\
\hline $\begin{array}{l}\text { Keinginan untuk } \\
\text { dekat }\end{array}$ & & tidak & ya & & & \\
\hline $\begin{array}{l}\text { Ingin lebih tau } \\
\text { tentang satwa }\end{array}$ & & tidak & ya & & & \\
\hline $\begin{array}{l}\text { Ingin memanggil } \\
\text { satwa }\end{array}$ & ya & tidak & & & & \\
\hline Ingin ketuk kaca & & tidak & ya & & & \\
\hline Ingin waspada & & tidak & tidak & & & \\
\hline Ingin memegang & ya & tidak & & & & \\
\hline Ingin beri makan & ya & tidak & & & & \\
\hline Ingin foto & & tidak & ya & & & \\
\hline
\end{tabular}

\section{Ketertarikan pengunjung terhadap penghalang Penghalang}

Pada tahap ini peneliti hanya melihat dari variabel visual yaitu kenyamanan, keunikan, keluasan, dan kealamian, karena peneliti hanya ingin mengetahui ketertarikan pengunjung terhadap desain penghalang kandang yang mana. Uji menggunkaan Kemiripan Subsets (Homogeneous Subsets Tukey HSD). Data tersebut dapat dilihat pada tabel dibawah ini

Tabel 3 Kemiripan Subsets (Homogeneous Subsets Tukey HSD) variabel atribut desain

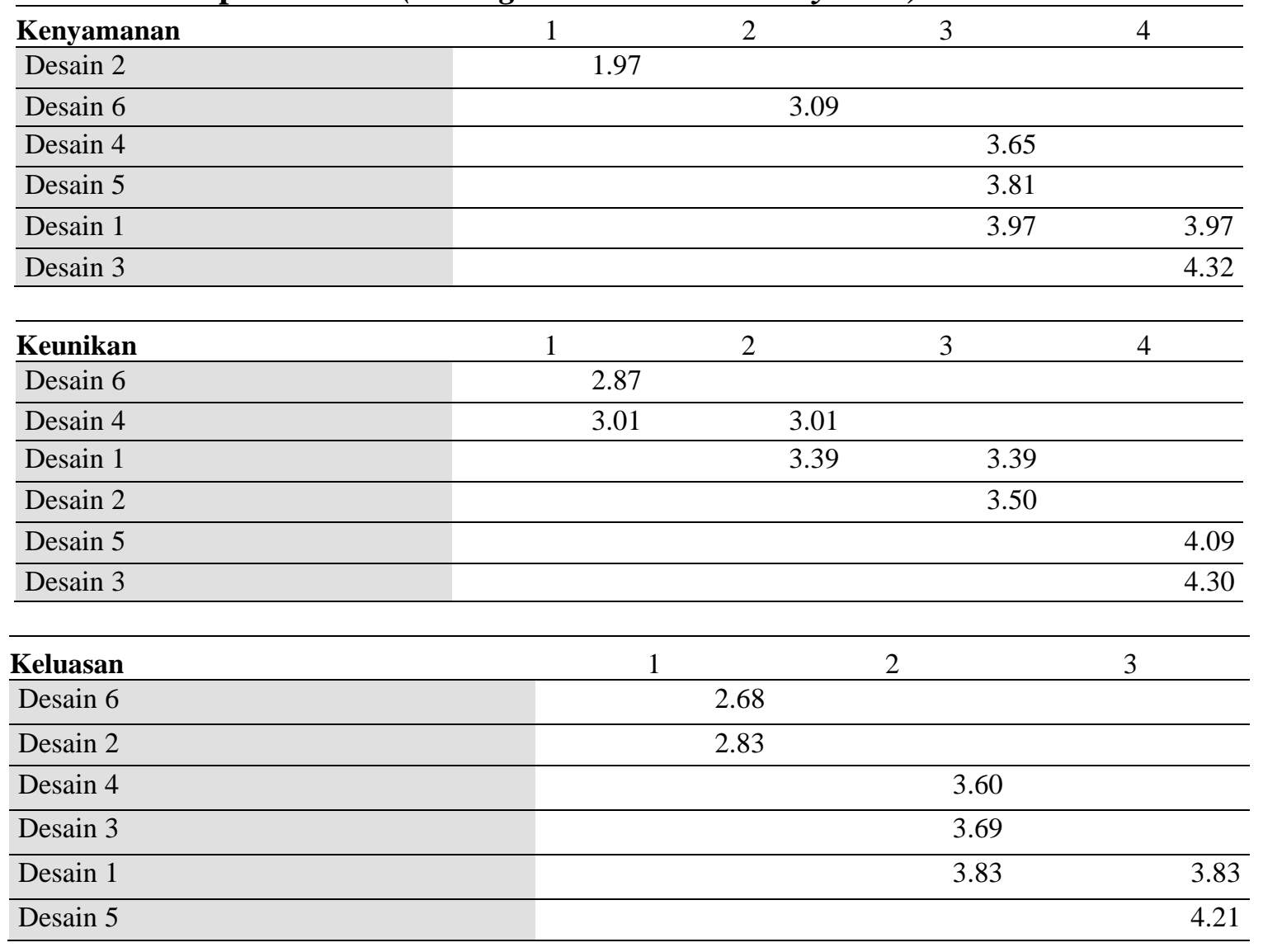

\section{Kealamian}




\begin{tabular}{lllll}
\hline & 1 & 2 & 3 & 4 \\
\hline Desain 6 & 2.68 & & & \\
\hline Desain 2 & & 3.12 & & \\
\hline Desain 3 & & 3.30 & & \\
\hline Desain 1 & 3.51 & 3.51 & \\
\hline Desain 4 & & & 3.75 & \\
\hline Desain 5 & & & & 4.39 \\
\hline
\end{tabular}

Pada gambar IV.3 terlihat ketertarikan konsumen pada atribut desain Reflection melebihi produk AMDK lain. Tabel IV.4 menunjukan perbandingan/perbedaan rata-rata setiap desain pada tabel kenyamanan menunjukan kelompok rata-rata yang secara signifikan mirip. Jika diamati pada atribut kenyamanan terdapat 4 kelompok namun hanya kelompok 1 (Desain 2) dan kelompok 2 (Desain 6) yang berbeda karena kelompok 3 dan 4 bersimpangan , dimana Desain 1 merupakan anggota kelompok 3 dan 4. Sehingga peneliti menyimpulkan bahwa kenyamanan tertinggi terdapat pada desain 3 (penghalang kaca) dengan nilai 4.32 yang memiliki nilai sinifikan kemiripan dengan desain 1 dengan nilai 3.97.

Selanjutnya variabel keunikan menunjukan kelompok rata-rata yang secara signifikan mirip. Jika diamati pada atribut keunikan terdapat 4 kelompok, pada kelompok 1 terdapat desain 6 dan desain 4 yang mana desain 4 juga merupakan kelompok 2 bersamaan dengan desain 1. Begitupula desain 1 yang merupakan kelompok 3 bersamaan dengan desain 2 . . Sehingga peneliti menyimpulkan bahwa keunikan tertinggi terdapat pada desain 3 (penghalang kaca) dengan nilai 4.30 yang memiliki nilai sinifikan kemiripan dengan desain 5 dengan nilai 4.09. lalu variable keluasan menunjukan kelompok rata-rata yang secara signifikan mirip. Jika diamati pada atribut keluasan terdapat 3 kelompok, pada kelompok 1 terdapat desain 6 dan desain 2 , pada kelompok 2 terdapat desain 4, 3 dan 1 yang mana desain 1 juga merupakan kelompok 3 bersama dengan desain 5. Sehingga peneliti menyimpulkan bahwa keluasan tertinggi terdapat pada desain 5 (parit basah) dengan nilai 4.21 yang memiliki nilai sinifikan kemiripan dengan desain 1 dengan nilai 3.83.

Terakhir variabel kealamian menunjukan kelompok rata-rata yang secara signifikan mirip. Jika diamati pada atribut keluasan terdapat 4 kelompok, pada kelompok 1 (desain 6) dan kelompok 4 (desain 5) berbeda karena desain 2 dan 3 bersimpangan, dimana desain 1 merupakan anggota kelompok 2 dan 3. Sehingga peneliti menyimpulkan bahwa kenyamanan tertinggi terdapat pada desain 5 (parit air) dengan nilai 4.39.

\section{Kaitan dengan Teori Proksemik}

Menurut (hall, 1966) ada 8 variabel yang mewakili sistem notasi perilaku proksemik dalam ruang mikro, yaitu peidentifikasian postur sex, sosiopetal-sosiofugal, kode kinestetik, kode sentuhan, kode visual, kode termal, kode olfaksi, dan kode suara. Desain sosiopetal dan sosiofugal dihadirkan dalam bentuk gambar setting denah kandang gajah, pengunjung diminta memilih area dimana dia akan berdiri menonton gajah. Hasilnya pengunjung cendrung memilih sosiofugal. Pada setting ini pengunjung tidak memiliki kesempatan bertatap muka pada pengunjung lainnya. Kemudian untuk penghalang kaca dan penghalang tali besi dinilai memiliki jarak yang paling dekat untuk berinteraksi dengan gajah. Kedekatan untuk melihat satwa dinilai menarik oleh pengunjung dan membuat waktu menonton lebih lama (Moss, Francis, \& Ensson, 2008) Sedangkan untuk posisi subordinal (desain 2) dan parit basah dinilai paling jauh. Karena desain posisi subordinal (desain 2) dan parit basah (desain 5) menyerupai desain kandang natural,hal ini mengurangi kontak mata langsung terhadap gajah. Keinginan beinteraksi cendrung lebih besar pada desain penghalang yang mendekatkan jarak dengan satwa di bandingkan jauh. Interaksi yang dianalisa dalam penelitian ini adalah adalah keinginan untuk memegang atau menyentuh satwa, memberi makan, melempar sesuatu kedalam kandang memanggil, dan berfoto. Pada perilaku 
kewaspadaan pengunjung lebih cendrung memilih posisi subordinal (desain 2) karena posisi pengunjung berada di atas membuat munculnya sikap menghormati pada gajah (Coe,1985). Perilaku kewaspadaan ini berkaitan dengan keinginan berdiri dekat atau tidak nya pengunjung terhadap penghalang. Hasil dari penelitian ini menyatakan bahwa pada posisi subordinal (desain 2) yang menampilkan gajah pada posisi atas memberikan kesan gajah terlihat sebagai satwa liar, sehingga pengunjung enggan mendekati area kandang dan kewaspadaan pengunjung dinilai paling tinggi pada desain ini. Namun sebaliknya, penghalang kaca membuat pengunjung ingin mendekati penghalang dan tidak merasa waspada, karena adanya batas fisik yang bersifat transparan. Keinginan pengunjung untuk memegang dikaitkan dengan variabel kode sentuhan. Pada penelitian ini desain yang dinilai paling tinggi dalam keinginan pengunjung untuk memegang adalah pada posisi dominan (desain 1) disusul dengan penghalang tali besi (desain 6). Selanjutnya variabel kode visual, bagaimana desain menyajikan kontak mata dengan gajah. Pada kesuluruhan desain pada studi ini mampu menyajikan kontak mata pengunjung terhadap gajah begitupun sebalinya. Namun yag dinilai memiliki visibilitas terbaik adalah penghalang kaca (desain 3). Terakhir kode suara, kode ini berkaitan dengan volume ucapan yang digunakan, berkaitan dengan keinginan pengunjung untuk mencari perhatian dengan memanggil satwa. desain penghalang yang memiliki nilai tinggi dalam perilaku memanggil satwa ada pada posisi dominan (desain 1). Variabel yang tidak disebutkan dalam pembahasan ini yaitu pengidentifikasian postur dan sex, kode termal (mengamati atau menikmati kehangatan pribadi, kode olfaksi yaitu kode penciuman mengacu pada jenis dan tingkat bau yang dideteksi oleh masing-masing seseorang satu sama lain, namun hal ini tidak di bahas dalam penelitian ini.

\section{Pembahasan}

Dalam studi sebelumnya menjelaskan mengenai variabel yang mempengaruhi perilaku di kebun binatang, yang awalnya dikemukakan oleh (Bitgood, Patterson, \& Benefield, 1987) beberapa variabelnya yaitu karakteristik arsitektur pameran, karakteristik hewan yang dipamerkan dan karakteristik pengunjung. Sebelumnya teori ini juga disebutkan dalam penelitian (Ridgway, Livingston, \& Smith, 2005) mengenai perbandingan perilaku pengunjung pada 6 desain kebun binatang dengan view bawah air, hasil dari penelitian tersebut menyebutkan bahwa desain penghalang kaca besar menghasilkan waktu menonton lebih lama dibanding yang kecil. Studi yang menereliti hubungan desain penghalang terhadap persepsi dan perilaku memang sudah banyak di dunia, namun untuk satwa spesifik seperti gajah masih tebatas tertutama di Indonesia.

Beberapa studi mengenai hal tersebut pernah dilakukan oleh (Yilmaz, Mumcu, Ozbilen, 2010) bahwa satwa di desain kandang tradisional terlihat tidak Bahagia dan terkesan dikurung sedangkan untuk desain kandang natural meningkatkan apresiasi untuk konservasi, kemudian penelitian lainnya oleh (Packer, Ballantyne, \& Luebke, 2018), (Hosey 2013 dalam (Sherwen \& Hemsworth, 2019) dan (Chiew, Hemsworth, Sherwen, Melfi, \& Coleman, 2019). Disini peneliti menyajikan desain yang berbeda dan hasilnya menunjukan bahwa semakin menarik suatu desain penghalang kandang maka perilaku positif dinilai semakin bertambah, sama dengan penelitian (Yilmaz,Dunzeli,Cigdem, 2017). Studi lain menemukan bahwa pengunjung kebun binatang lebih sering berhenti dan menghabiskan lebih banyak waktu untuk menonton pada desain kandang yang dapat memperlihatkan satwa itu dengan jelas (Godinez \& Fernandez, 2019). Lalu studi Philpot (1996) dalam Davey 2006) menemukan bahwa pengunjung menghabiskan lebih banyak waktu untuk mencari dan mengamati perilaku satwa di kandang naturalistik. Pada penelitian ini juga menemukan bahwa ketika responden di sajikan gambar desain penghalang kaca masih banyaknya keinginan pengunjung untuk melakukan pengetukan kaca untuk mencari perhatian gajah, meskipun desain penghalang yang disajikan dinilai sudah sangat menarik dan unik menurut responden. Keunikan didapatkan dari peneliti yang mencoba menampilkan altenatif desain penghalang yang jarang 
(baru) di temukan pada kandang gajah di Indonesia seperti penghalang kaca, parit basah, posisi tampil dominan dan subordinal. Hasilnya menunjukan bahwa penghalang kaca dinilai paling unik disusul dengan penghalang parit basah yang dinilai lebih terlihat natural dibandingkan dengan penghalang lain yang disajikan. Penghalang kaca juga menghasilkan keinginan responden untuk mengamati lebih lama dan mengetahui lebih jauh mengenai tingkah laku satwa di dalam kandang karna dinilai lebih jelas. Selain penghalang yang terkesan unik, peneliti juga menyajikan penghalang kandang pagar tali besi yang terkesan tradisional, pembatas kandang seperti ini membuat satwa terlihat seperti tawanan. Dilihat dari hasil penelitian bahwa desain penghalang tali besi menciptakan kesan bosan dan kesan pembatasan. Hal ini serupa dengan studi ( Nakamichi, 2007) yang menyuguhkan desain lama (desain tradisional) dan desain baru (desain natural) pengunjung lebih banyak berhenti dan menghabiskan waktu menonton lebih lama di desain kandang baru karena daya tariknya lebih besar.

Penelitian ini juga mengahasilkan bahwa parit basah yang terkesan seperti kolam besar memiliki persepsi luas, bebas dan natural seperti di habitat aslinya. Pemberian penghalang parit basah yang terkesan naturalistik akan membuat terciptanya ilusi hewan dalam habitat alami. Kemudian mengenai posisi relative pengunjung, antara posisi dominan dan sub ordinal yang terinspirasi dari penelitian (Moriis, 1967 dalam Jon C. Coe 1985) yang berasumsi bahwa individu yang dominan cendrung memimpin, mengarahkan dan mengajari. Sedangkan peran bawahan cendrung mengikuti, belajar dan menerima lingkungan. Hal ini menunjukan bahwa desain kandang yang menempatkan pengunjung dalam posisi dominan pada pengunjung dapat mempengaruhi perilaku untuk tidak belajar dan berprilaku negatif, sedangkan untuk posisi subordinal pada pengunjung dapat mempengaruhi sikap menghormati dan perilaku positif terhdap satwa. Kedua posisi relative ini menjadikan adanya sebuah Batasan kandang yang dimaknai dengan perbedaan leveling. Sesuai dengan penemuan penelitian ini bahwa posisi dominan pada hewan memberikan kesan kebuasan dan berbahaya terhadap satwa sehingga tidak adanya keinginnan responden untuk memberi makan, memegang, mencari perhatian, mendekati penghalang, ingin tahu satwa lebih banyak dan berfoto dari jarak dekat. Kewaspadaan yang terjadi pada desain ini dinilai paling tinggi karna posisi gajah berada di atas sehingga responden lebih menghormati. Untuk posisi subordinal yang dinilai lebih mempengaruhi perilaku negatif juga sesuai dengan temuan penelitian ini bahwa perilakuperilaku negatif seperti keinginan memberi makan, memanggil, dan memengang satwa cendrung terjadi. Dapat disimpulkan bahwa jika dilihat dari penilaian pengunjung mengenai batas atau desain penghalang kandang gajah pada sebuah kebun binatang yaitu penghalang harus mampu mendekatkan pengunjung dengan satwa sehingga pengunjung dapat melihat gajah lebih jelas. Selain mendekatkan, batas antara area satwa dan area pengunjung juga harus jelas sehingga pengunjung akan merasa aman.

Hasil analisa juga menunjukan ketika desain denah sebuah kandang gajah di tampilkan, pengunjung berkomunikasi berdiri di area sosiofugal. Dimana pengunjung tidak ingin berkomunikasi secara bertatapan langsung dengan pengunjung lain, fokus mereka hanya ingin dekat dan berinteraksi kepada satwa. Inteaksi yang biasanya dilakukan di kebun binatang adalah keinginan untuk memegang atau menyentuh satwa, memberi makan dan melempar sesuatu kedalam kandang. Pada kasus pemberian makan gajah distimuli menggunakan makanan yang dibawa oleh pengunjung, sehingga gajah yang mungkin sedang lapar lalu menghampiri dan mengambil makanan tersebut. Seperti kasus pada penelitian (Yuanting 2011) yang menyebutkan bahwa orang utan yang diberi makan menghasilkan perilaku mengemis, hal ini mengartikan setiap ada pengunjung orang utan akan mendekat sambil meminta makanan. Hal ini menyimpulkan bahwa satwa akan mengurangi besaran ruang peribadinya (jarak terbang) terhadap manusia jika ia memiliki kebutuhan atau keinginan seperti makanan (lapar). 
Pesan lain yang tidak disadari jarak berdiri menjauh pengunjung terhadap penghalang menandakan ketakutan terhadap gajah. Ketakutan tersebut biasanya berasal dari pemahaman dan pengalaman masing-masing seseorang. Ketakutan tersebut akan menimbulkan kekhawatiran yang kemudian memunculkan sikap kewaspadaan, pada kejadian ini akan menimbulkan interaksi yang minim. Perilaku kewaspadaan ini berkaitan dengan keinginan berdiri dekat atau tidak nya pengunjung terhadap penghalang. Penghalang yang dinilai pengunjung menciptakan perilaku ingi dekat dengan peghalang adalah penghalang kaca (desain 3), pada desain ini juga dinilai tidak adanya sikap waspada pengunjung terhadap gajah. karna adanya batas fisik yang bersifat transparan. Sifat transparan ini sering juga disebut dalam bidang arsitektur dengan sebutan transparansi, yang merupakan dematerialisasi (proses merubah materi menjadi abstrak) dari bahan yang terbuka dan tembus cahaya (Polla, Paath, \& P.V., 2011) Dalam transparansi material yang biasanya digunakan adalah kaca. Pemaknaan kaca sebagai penghalang transparan menciptakan makna yang lebih dari sekedar penghalang area pengunjung dan gajah. Menurut penelitian (Lestari \& Alhamdani, 2014) kaca memiliki nilai yang memiliki konektivitas visual dan integrasi antara bangunan, ruang dan lingkungannya. Sifat transparan ini dapat membatasi ruang, tetapi tetap meneruskan secara visual (Aziiz, 2015) Kewaspadaan tidak hanya terjadi pada manusia saja, satwa juga merasakan hal tersebut. heini heidiger menjelaskan dalam penelitiannya mengenai perilaku binatang di kebun binatang dan sirkus yang dibedakan menjadi: Jarak terbang, jarak kritikal, jarak pribadi, dan jarak sosial. namun pada manusia jarak terbang dan jarak kritikal dihilangkan karena hal tersebut tidak berhubungan dengan konteks kehidupan manusia (Suwartono, 200).

Dalam kajian proksemika hal ini di sebut faktor kinestetik (jarak dan gerak tubuh). Hal ini juga mengacu pada jarak yang berbeda antara manusia untuk menyentuh satu sama lain. Hasil analisa penghalang yang dinilai memiliki tingkat keingin menyentuh paling tinggi adalah pada posisi dominan, dimana ketinggian area pengunjung lebih unggul dibandingkan satwa. Pada posisi ini pengunjung akan cendrung merasa berkuasa dan berperilaku seenaknya terhadap satwa (Coe, 1985). Mungkin saja saat pengunjung menyodorkan tangannya gajah berpikir bahwa manusia memberikan makanan, padahal pengunjung hanya ingin mencari perhatian ataupun memegang. Menyentuh satwa di kebun binatang sebenarnya dilarang, karena dapat menimbulkan dampak buruk baik dari segi pengunjung atau satwa. Banyak pengunjung yang memiliki keinginan untuk menyentuh gajah di dalam kandang, namun hal ini di minimalisir oleh pihak kebun binatang demi menghindari kejadian yang tidak diinginkan.

Faktor lain yang dibahas dalam proksemik adalah kode visual, dalam penyajian kontak mata dengan gajah, desain penghalang harus luas dan jelas (Ridgway, Livingston and Smith,2005) sehingga visibility gajah dapat dirasakan pengunjung dengan baik dan pesanpesan yang ingin ditampilkan oleh kebun binatang tersampaikan. Keseluruhan desain menampilkan kejelasan dan visibiltas dengan menyajikan kontak mata terhadap gajah, begitu pula dengan gajah juga dapat melakukan kontak mata terhadap pengunjung. Namun hal ini semakin diminimalisirkan di beberapa kebun binatang untuk menciptakan pengalaman seperti pada (Moss, Francis, dan Esson,2008) pada studinya dalam mengukur perilaku menonton menurut ukuran area tampilan. Pada penelitian ini kode visual dapat terlihat seperti desain parit basah yang dinilai memiliki jarak cukup jauh sehingga kontak mata tidak terjadi secara langsung.

Terakhir peneliti membahas mengenai Kode suara. Jika dinilai dari jenis penghalang yang disajikan pengunjung cendrung ingin berinteraksi mencari perhatian dengan memanggil gajah pada posisi tampil dominan (Desain 1). Perilaku ini mungkin saja terjadi di semua desain, sehingga perlu adanya penanganan untuk mengurangi dampak ini. Variabel lain dalam proksemik menurut (hall, 1966) yang tidak disebutkan dalam pembahasan ini yaitu pengidentifikasian postur dan sex, kode termal (mengamati atau menikmati kehangatan 
pribadi, kode olfaksi yaitu kode penciuman mengacu pada jenis dan tingkat bau yang dideteksi oleh masing-masing seseorang satu sama lain. Namun hal ini tidak di bahas dalam penelitian ini.

\section{SIMPULAN DAN SARAN}

Keseluruhan desain yang disajikan, desain penghalang kaca dinilai paling menarik dan nyaman karena mampu memperlihatkan gajah secara jelas dan dekat. Hal ini membuat terjadinya waktu menonton lebih lama. Ketertarikan pada suatu desain juga mempengaruhi ruang pribadi pengunjung. Semakin pengunjung tertarik maka ruang pribadinya semakin kecil atau jarak terhadap penghalang akan sangat dekat. Sedangkan untuk satwa akan mengurangi besaran ruang peribadinya (jarak terbang) terhadap manusia jika ia memiliki kebutuhan atau keinginan seperti makanan (lapar). Pada perilaku ingin dekat dengan penghalang dan kesan paling aman juga dinilai paling tinggi dibandikan dengan 5 penghalang lain yang disajikan. Hal ini membuat kecilnya perilaku waspada pada gajah. Namun persepsi pengunjung pada gajah terlihat jinak. Penghalang kaca ini memberikan kesan trasparan terhadap area pengunjung dan gajah yang dijadikan sebuah konektivitas visual dan integrasi. Sehingga desain ini dinilai ideal untuk desain penghalang kandang gajah kedepannya

\section{DAFTAR RUJUKAN}

Aziiz, A. D. (2015). Penggunaan Material Dominan Kaca terhadap Bangunan. Prosiding Temu Ilmiah IPLBI 2015.

Davey, G., Henzi, P., \& Higgins, L. (2005). The Influence of Environmental Enrichment on Chinese Visitor Behavior.

Nakamichi, M. (2007). Assessing the Effects of New Primate Exhibits on Zoo Visitors' Attitudes and Perceptions by Using Three Different Assessment Methods.

Altman, I. (1975). The Environment \&Social Behaviour, Privacy. Personal Space. Territory. Crowding. . Monterey : Brooks/Cole publishing company.

Bell, Paul , P. A. (1996). Environmental Psychology (4th ed.). USA: Harcourt Brace.

Bitgood, S., Patterson, D., \& Benefield, A. (1987). Exhibit Design and Visitor Behavior: Empirical Relationships. Environtment and behavior, Vol 20 No.4.

Chiew, S. J., Hemsworth, P. H., Sherwen, S. L., Melfi, V., \& Coleman, G. J. (2019). The Effect of Regulating Zoo Visitor-Penguin Interactions on Zoo Visitor Attitudes.

Coe, J. C. (1985). Design and Perception: Making the Zoo Experience Real. Zoo Biology, Volume 4, Number 2.

Coe, J. C. (1994). Landscape Immersion-Origin and Concepts in Landscape Immersion Exhibits How are They Proving as Educational Settings? AZA Annual Conference Proceedings.

Darwis, M. H. (2006). Emosi Penjelajahan Religio-Psikologis tentang Emosi Manusia di dalam Al-Qur'an. Jakarta: Erlangga.

Davey, G. (2006). Visitor behavior in zoos: A review.

Davey, G. (2007). Visitors' Effects on the Welfareof Animals in the Zoo: A Review. JOURNAL OF APPLIED ANIMAL WELFARE SCIENCE, 10(2), 169-183.

Deddy, H. (2005). Psikologi arsitektur : pengantar kajian lintas disiplin. Jakarta: Grasindo.

Durrheim, D., \& Leggat, P. (1999). Risk to tourists posed by wild mammals in South Africa. Journal of Travel Medicine 6.

Eymeren, M. M. (2014). Memahami Persepsi Visual : Sumbangan Psikologi Kognitif dalam Seni dan Desain.

Febriani , P., \& P.VPaath. (2011). Transparansi Dalam Arsitektur. Media Matrasain Volume 8 No 3, 79-93.

Fernandez, E. J., Tamborski, M. A., Pickens, S. R., \& Timberlake, W. (2009). Animal-visitor interactions in the modern zoo: Conflicts and interventions. 
Fielder, F., \& Wheeler, W. (1985). A Survey of Visitors in the Woodland Park Zoological Gardens. The Zoological Foundation of Woodland Park. WA: Seattle.

Fine, A. H. (2010). Handbook on Animal-Assisted Therapy. USA: Academic Press in an imprint of Elsevier.

Godinez, A. M., \& Fernandez, E. J. (2019). What Is the Zoo Experience? How Zoos Impact a Visitor's Behaviors, Perceptions, and Conservation Efforts.

Gupta, B. K. (2008). Barrier Designs For Zoos. New Delhi: Central Zoo Authority.

Halim, D. (2005). Psikologi Arsitektur : Pengantar Kajian Lintas Disiplin. Jakarta: Grasindo Gramedia Widiasarana Indonesia.

Hall, E. T. (1968). Proxemics. Chicago Jurnal.

Hall, E. T. (1982). The Hidden Dimention. United States: Anchor Books.

Hemsworth, P., \& Coleman, G. (2011). Effects of stockperson behaviour on animal welfare and productivity.

Hosey G, G., Melfi V , V., \& Pankhurst, S. (2013). Zoo animals: behaviour, management and welfare. United Kingdom: Oxford University Press.

Hosey, G. (2013). Hediger Revisited: How Do Zoo Animals See Us? Journal of Applied Animal Welfare Science, 16;388-359.

Issac, S., \& Michael, W. (1984). Handbook in research and evaluation. San Diego: Edits.

Judd, J. B., Weladji, R. B., \& Louis , L. (2019). Activity budget and spatial distribution of Bennett's wallabies (Macropus rufogriseus) in open versus closed exhibit designs. Wiley Zoologi.

Judd, J. B., Weladji, R. B., Lazure, L., \& Pare, P. (2019). Activity Budget and Spatial Distribution of Bennett's wallabies (Macropus rufogriseus) in Open versus Closed Exibit Design. Zoo Biology / Volume 38, Issue 3.

Kasiram, M. (2008). Metodologi Penelitian. Malang: UIN-Maliki Press Malang.

Keswanto, \& Dedy. (2012). Statistik Untuk Pemula \& Orang Awam. Jakarta: Laskar Aksara.

Lestari , L., \& Alhamdani, M. R. (2014). Penerapan Material Kaca dalam Arsitektur. Langkau Betang Vol 1, No 2 (2014).

Mccormick, W. D., \& Melfi, V. (2004). A preliminary assessment of how zoo visitors evaluate animal welfare according to enclosure style and expression of behavior.

Mohamed , R. K., \& Dominic, L. (2015). La mesure de la satisfaction des visiteurs d'un parc zoologique : L'exemple du Parc Safari au Quebec.

Moss, A., Francis, D., \& Ensson, M. (2008). The Relationship between Viewing Area Size and Visitor Behavior in an Immersive Asian Elephant Exhibit.

Mulyana, D. (2005). Ilmu Komunikasi Suatu Pengantar. Bandung: PT. Remaja Rosdakarya.

Nur'aini, R. D., \& Ikaputra, I. (2019). Teritorialitas dalam Tinjauan Ilmu Arsitektur.

Nur'aini, R. D., Nur, R. G., \& Setiawan, T. (2018). Pengaruh Desain Lansekap Terhadap Perilaku Penjunjung Pada Taman Kota Liwan Lake Park Guangzhou, China.

Octavianti, M. (2016). Komunikasi Nonverbal Proksemik di Rumah Tidak Layak Huni. Jurnal Kajian Komunikasi, Volume 4, No.1.

Packer, J., Ballantyne, R., \& Luebke, J. F. (2018). Exploring the Factors That Influence Zoo Visitors' Perceptions of the Well-Being of Gorillas: Implications for Zoo Exhibit Interpretation.

Polla, F., Paath, \& P.V. (2011). Transparansi dalam Arsitektur. Media Matrasain Vol 8 No 3, Nopember 2011.

Priyatno. (2016). Belajar Alat Analisis Data dan Cara Pengolahannya Dengan SPSS. Yogyakarta: Penerbit Gaya Media.

Ridgway, S. C., Livingston, M., \& Smith, S. E. (2005). Visitor Behavior In Zoo Exhibits With Underwater Viewing. Visitor Studies today a publication of the visitor study association. 
Serap, Y., \& Ali , Ö. (2011). Hayvanat bahçeleri tasarım ilkeleri ve tipolojileri Design principles and typologies of zoos. SDU Faculty of Forestry Journal 12, 47-56.

Sherwen, S. L., \& Hemsworth, P. H. (2019). The Visitor Effect on Zoo Animals: Implications and Opportunities for Zoo Animal Welfare.

Slatch, A. K. (2015). Landscape Immersion UNDERSTANDING ZOO DESIGNS.

Sugiyono. (2015). Metode Penelitian Kombinasi (Mix Methods). Bandung: Alfabeta.

Sugiyono. (2019). Metode Penelitian Kuantitatif Kualitatif dan R\&D. Bandung: Alfabeta.

Yılmaz, S., Düzenli, T., \& Çiğdem, A. (2017). Visitors Experiences in Different Zoo Exhibits. YILMAZ et al., Curr. World Environ., Vol. 12(1), 17-27 (2017).

Yilmaz, S., Mumcu, S., \& Ozbilen, A. (2010). Effects of spatial differences on visitor perceptions at zoo exhibits.

Yuanting , C., Peter, A. T., \& Daiqin, L. (2011). Visitor Effect on Zoo Orangutans in two novel, Naturalistic Enclosures. Applied Animal Behviour Science Volume 133, Issues $1-2,78-86$.

\section{Daftar Pustaka dari Surat Kabar:}

Anugrahadi, Ady. Kena OOT saat Lempar Botol ke Orang utan, Pengunjung Ragunan dibawa ke Kantor Polisi. (17 Juni 2018). Merdeka.com

Wardani, Hary Lukita. Kuda Nil Dicekoki Anggur Merah, Taman Safari Tingkatkan Pengawasan. (16 November 2017). Detik.com

Solehudin, Mochammad. Orang Utan yang Dilempari Rokok Pengunjung Bunbin Bandung . (16 November 2017). Detik.com

Solehudin, Mochammad. Astaga! $20 \mathrm{Kg}$ Plastik Ditemukan di Perut Jerapah Mati di Surabaya . (3 Maret 2012). Detik.com 